\title{
Does Age Matter? Examination of Hungarian Basketball Coaches' Pedagogical Beliefs and Professional Attitudes
}

\author{
Judit Balogh ${ }^{1}$, Gabriella Trzaskoma-Bicsérdy ${ }^{1}$ \\ ${ }^{1}$ Department of Sports Games, University of Physical Education, Budapest, Hungary \\ Correspondence: Judit Balogh, Department of Sports Games, University of Physical Education, Budapest, Hungary.
}

Received: April 1, 2020

Accepted: June 7, 2020

Online Published: June 10, 2020

doi:10.11114/jets.v8i7.4786

URL: https://doi.org/10.11114/jets.v8i7.4786

\begin{abstract}
Sports coaching in Hungary is an established profession. The coaching workforce, which is diverse in terms of age and coaching experience, is trained and paid. This study aimed to illustrate the impact of age on coaches' values, beliefs and attitudes towards various aspects of their jobs. A total of 152 basketball coaches (105 male and 47 female) working in Hungary, with an average of 12.9 years $( \pm 11.5)$ coaching experience participated in an online survey. They were categorized into five age-groups i.e. $<23$ years, $23-35$ years, $36-45$ years, $46-55$ years and $>55$ years; one-way analysis of variance and Tukey's post hoc tests were used to identify the differences between groups. Regardless of their ages, coaches shared similar viewpoints on a range of aspects concerning coaching. Significant distinctions were mainly seen between coaches aged over 55 years and other age-groups suggesting that age has some effect on coaches' beliefs and attitudes. Because respondents' age and coaching experience were closely related, these differences could be attributed to age and commensurate experience.
\end{abstract}

Keywords: age-groups, roles, values, behaviours, personal characteristics, experience

\section{Introduction}

Physical activity is not only a useful way of spending free time, but also has numerous other benefits including preventing health problems and maintaining good physical and mental wellbeing. Therefore, it is vital that people regularly take part in organised sports with clubs being the most suitable environment to promote active participation. Several authors have shown that participation in sports is associated with several positive impacts on physical, psychological and social development (Cronin \& Allen, 2018; Merkel, 2013; Strachan, Côté \& Deakin, 2011). The participation of young persons in sports is a great opportunity to inculcate values and learn useful life lessons for athletes (Watson, Connole \& Kadushin, 2011). Taking into consideration that very few athletes have the potential to attain the elite level, all athletes, regardless of talent and ability, ought to feel that their participation in sports valuable and worthwhile. Nevertheless, talented athletes require appropriately planned and executed long-term training programmes, to attain top-level status.

Coaching is a very complex and demanding job. Coaches not only teach technics and tactics, but are also mandated to satisfy a range of expectations. These responsibilities include the development of trainees' physical, personal and social skills (Strachan et al., 2011), supporting athletes' learning, and being leaders, and modelling amiable attitudes and behaviours. To effectively fulfil their roles, coaches ought to have broad, sound pedagogical and professional knowledge in their fields. How coaches put this understanding into practice fundamentally impact their athletes' perception of the quality of sports participation and their attitudes towards sports going in the present and the future (Miller \& Siegel, 2017; Prichard \& Deutsch, 2015; Rottensteiner, Laakso, Pihlaja \& Konttinen, 2013). The sports environment established is based on the coaches' personal characteristics, the perception of the particular sports setting, and the principles of coaches' philosophies. Personality traits and attitudes however, are supposed to change over time (Caspi \& Roberts, 2009; Schwaba \& Bleidorn, 2017); maturation, changes in the social environment, life events, work experiences and different forms of education impact on individual's perceptions (Gilbert \& Trudel, 2001; Smola \& Sutton, 2002). Therefore, coaches of different ages and in different stages of life and career have different views concerning their jobs. Nevertheless, principles of each sport reflect the underlying values and beliefs towards various aspects of coaching which in turn determine their methods, attitudes and behaviours in their work (Cushion, 2010).

Sports coaching in Hungary is an established profession; the workforce is formally trained and paid. A previous 
sport-specific experience as an athlete is prerequisite for individuals serving at any level in coaching positions in popular sports. This experience is a valuable source of knowledge for coaches (González-Rivera, Campos-Izquierdo, Villalba \& Hall, 2017) to draw from especially during the initial years of their careers. Since coaching is a long-term career opportunity, coaches are of different ages and have varying durations of work experience which may lead to preconceptions about younger and older coaches. However, empirical evidence from this field in sport contexts is limited.

Age stereotyping occurs in workplaces. Older professionals are thought to possess limited abilities, are thought of as being unmotivated, resistant to change and unable to learn new things (Posthuma \& Campion, 2009). Conversely, in the literature, it has been proven that several aspects older workers do not differ from that younger ones $(\mathrm{Ng} \&$ Feldman, 2012). Additionally, older persons can even be perceived to be more conscientious and balanced (Bertolino, Truxillo \& Fraccaroli, 2013). Prejudices are not limited to older professionals (Ilisanu \& Andrei, 2018), younger professionals experience prejudice too. Young persons are perceived as uncultured, immature (North \& Fiske, 2012), overconfident, uncommitted and being motivated by personal gains only (Bencsik, Juhász \& Horváth-Csikós, 2016).

Nevertheless, differences between the characteristics of different generations of school teachers do exist (Geeraerts, Vanhoof \& Van Den Bossche, 2019). Younger teachers have been shown to be more creative and innovative, whereas older teachers had broader subject matter knowledge and management skills. As regards conflict management strategies, older teachers were more likely to avoid conflict when compared to their younger colleagues (Vrbnjak, Videmšek \& Štihec, 2011).

In Slovene sports contexts, younger coaches described themselves as more friendly, empathic, conscious, accurate, persistent, open to novelties, agreeable and better at emotional management. Older coaches on the other hand, were shown to be less friendly, less altruistic, less open to changes, less likely to avoid confrontations with other coaches and staff members and unwilling to cooperate. Their behaviour was more often democratic or autocratic (Dimec \& Kajtna, 2009). Older coaches also reported being dissatisfied with their status having more work-related problem (Kajtna \& Topic, 2017). However, no differences were identified when comparing motivation to achieve goals and social skills by age of coach (Dimec \& Kajtna, 2009).

Generational gaps between coaches and players often exist. The larger the gap, the greater the likelihood that coaches would need to make compromises, consider differences in perceptions and make efforts to be more tolerant, patient, empathic and behave consciously during practice sessions and games. Since the primary goal of organised sports is to maintain participation, it is essential to establish a common ground between both parties. Because athletes will work with coaches of different ages throughout the years of their careers, if younger and older coaches' philosophies vary to a great extent, the transition of an athlete from one coach to another is likely to be problematic.

Limited information exists on generational differences in sports context. This paper explores the impact of a coaches' age has on basketball coaches' pedagogical and professional values, beliefs and attitudes.

\section{Methods}

\subsection{Participants}

A total of 152 basketball coaches $(n=152)$ participated in the survey; their average age was 39.7 years $( \pm 11.5)$. They had an average playing career of 17.4 years, with $32.2 \%$ of them being active players at the time of the survey. On average, they worked with two teams; $78.4 \%$ coached youth teams, or both youth and senior/U20 teams.

Coaches were categorised into five age-groups:

1. aged less than 23 years

2. aged 23 and 35 years

3. aged 36 and 45 years

4. aged 46 and 55 years

5. older than 55 years

The respondents' demographics are presented in Table 1. The majority of coaches in were aged between 23 and 45 years, with an average of 12.9 years $( \pm 10.4)$ of coaching experience. 
Table 1. Descriptive characteristics of the sample $(n=152)$

\begin{tabular}{lc|ccccc}
\hline & Total & Under $\mathbf{2 3}$ & $\mathbf{2 3 - 3 5}$ & $\mathbf{3 6 - 4 5}$ & $\mathbf{4 6 - 5 5}$ & Over 55 \\
\hline Total sample \% & 100.0 & 4.6 & 33.6 & 32.9 & 15.8 & 13.1 \\
\hline Coaching experience (years) & 12.9 & 1.3 & 6.0 & 11.0 & 22.4 & 28.1 \\
\hline Gender of the coach \% & & \multicolumn{5}{|c}{ within columns } \\
women & 30.9 & 42.9 & 19.6 & 42.0 & 25.0 & 35.0 \\
men & 69.1 & 57.1 & 80.4 & 58.0 & 75.0 & 65.0 \\
\hline General educational level \% & & & & & & \\
High school & 25.0 & 100.0 & 27.5 & 20.0 & 16.7 & 15.0 \\
University & 75.0 & - & 72.5 & 80 & 83.3 & 85.0 \\
\hline Coaching qualification \% & & & & & & \\
Unqualified & 13.2 & 100.0 & 23.5 & 2.0 & - & - \\
Vocational & 40.8 & - & 49.0 & 44.0 & 33.3 & 35.0 \\
University & 46.0 & - & 27.5 & 54.0 & 66.7 & 65.0 \\
\hline Teams' age-group \% & & & & & & \\
U12 & 34.0 & 66.7 & 37.9 & 23.2 & 36.2 & 40 \\
U14 & 15.0 & 11.1 & 13.7 & 17.2 & 13.8 & 15.5 \\
U16 & 14.0 & 11.1 & 12.6 & 14.1 & 13.8 & 17.8 \\
U18 & 15.4 & 11.1 & 15.8 & 18.2 & 15.5 & 8.9 \\
U20-senior & 21.6 & - & 20.0 & 27.3 & 20.7 & 17.8 \\
\hline
\end{tabular}

\subsection{Data Collection and Data Analysis}

A questionnaire was designed based on an extensive review of the literature and documented behaviour of coaches. In the questionnaire's introduction, the study's purpose was explained and participants were assured of the confidentiality of their responses. The first part of the survey questionnaire contained questions related to participants' demographic information (i.e. age, gender, educational attainments and number of coaching years), whereas the second part contained 40 items (organized into groups) focusing on three key aspects of a coach's job:

a) pedagogical and professional roles and responsibilities,

b) personal characteristics,

c) attitudes and behaviours.

The link to the online survey was emailed to all basketball coaches possessing a valid license by the Hungarian Basketball Federation. Participants were asked to rate different items on a five-point Likert-scale, ranging from 5 (extremely important/strongly agree/fully acceptable) to 1 (not at all important/strongly disagree/not at all acceptable). E.g.: "Please rate the importance of the following items in the coaching job" or "How much do you agree with the following statements?" The survey completion rate was thirty percent. Summarized data from the online survey tool was transferred to the STATISTICA 13.2 analysis program. A computed Cronbach's alpha of 0.791 ensured testing reliability.

In addition to a descriptive analysis, one-way analysis of variance (ANOVA) test was used to detect significant differences between the five groups (Kühl et al., 2019; Norman, 2010; Ocak, Özçalişan, \& Kuru, 2010). Tukey’s HSD post hoc analysis was run for between groups' comparisons. The significance level was set to five percent $(\mathrm{p}<0.05)$.

\section{Results}

Regardless of the coach's age, the importance of their pedagogical and professional roles and responsibilities was rated very highly. The highest score was given to 'professional knowledge' $(\mathrm{M}=4.85, \mathrm{SD}=0.37)$ especially by coaches aged over 55 years old. The least appreciated item was 'developing elite players' $(\mathrm{M}=3.32, \mathrm{SD}=0.90)$ with very little differences in scores by age-group.

These results suggest that coaches of different age groups share similar views on many important aspects of coaching; this is because significant differences were only seen on four items. Although it is difficult to draw a clear-cut 
distinction between pedagogical and professional facets of the job, all the detected dissimilarities are connected to pedagogical functions. Nevertheless, no patterned differences were observed between different groups.

The educating role statistically differed between the groups with the oldest age group rating it the highest $(\mathrm{M}=4.45)$ when compared to 36-45-year-old professionals $(\mathrm{M}=3.84)$. However, when comparing other pedagogical aspects, no significant differences were found between these two cohorts (i.e. $>55$ years and 36-45 year olds). The youngest coaches held slightly different views from older coaches regarding the importance of 'teaching values' $(\mathrm{M}=4.00)$ and 'creating a positive environment' $(\mathrm{M}=4.29)$. Although motivating was rated highly by each age group, it was more appreciated by the oldest coaches $(M=4.85)$ than coaches between 46 and 55 years $(M=4.43)$ (Table 2).

Table 2. Average ratings of pedagogical and professional roles and responsibilities by different age-groups of basketball coaches

\begin{tabular}{|c|c|c|c|c|c|c|c|c|c|c|c|}
\hline \multirow{2}{*}{ Items } & \multicolumn{2}{|c|}{ Under 23} & \multicolumn{2}{|c|}{ 23-35 } & \multicolumn{2}{|c|}{ 36-45 } & \multicolumn{2}{|c|}{$46-55$} & \multicolumn{2}{|c|}{ over 55} & \multirow[b]{2}{*}{$\mathbf{p}$} \\
\hline & $\mathbf{M}$ & SD & $\mathbf{M}$ & SD & $\mathbf{M}$ & SD & $\mathbf{M}$ & SD & $\mathbf{M}$ & SD & \\
\hline Coaches are first of all educators & 3.86 & 0.90 & 4.12 & 0.68 & $3.84 *$ & 0.91 & 4.25 & 0.90 & $4.45^{*}$ & 0.69 & $0.040 *$ \\
\hline Being an example & 4.71 & 0.49 & 4.75 & 0.48 & 4.73 & 0.53 & 4.71 & 0.46 & 4.90 & 0.31 & 0.695 \\
\hline Teaching values & $4.00^{*}$ & 1.00 & 4.57 & 0.78 & $4.73^{*}$ & 0.49 & $4.79 *$ & 0.41 & 4.70 & 0.47 & $0.035^{*}$ \\
\hline Character development & 4.29 & 0.76 & 4.65 & 0.52 & 4.65 & 0.48 & 4.38 & 0.71 & 4.60 & 0.60 & 0.176 \\
\hline Creating a positive environment & $4.29 *$ & 0.76 & $4.80^{*}$ & 0.40 & 4.78 & 0.42 & 4.50 & 0.59 & 4.75 & 0.55 & $0.014 *$ \\
\hline Setting and keeping rules & 4.57 & 0.79 & 4.69 & 0.51 & 4.67 & 0.52 & 4.38 & 0.58 & 4.50 & 0.89 & 0.222 \\
\hline Maintaining discipline & 4.29 & 0.95 & 4.39 & 0.83 & 4.57 & 0.68 & 4.13 & 0.74 & 4.16 & 1.07 & 0.161 \\
\hline Motivating & 4.71 & 0.76 & 4.80 & 0.40 & 4.80 & 0.46 & $4.43^{*}$ & 0.59 & $4.85^{*}$ & 0.37 & $0.016^{*}$ \\
\hline Differentiating in training & 3.86 & 0.69 & 4.00 & 0.95 & 4.35 & 0.69 & 3.92 & 0.78 & 4.25 & 0.85 & 0.118 \\
\hline Professional knowledge & 4.71 & 0.49 & 4.86 & 0.40 & 4.88 & 0.33 & 4.71 & 0.46 & 5.00 & 0.00 & 0.099 \\
\hline Developing elite players & 3.29 & 1.11 & 3.20 & 0.96 & 3.39 & 0.76 & 3.33 & 0.96 & 3.45 & 0.94 & 0.798 \\
\hline Developing multiple skills & 4.86 & 0.38 & 4.65 & 0.66 & 4.67 & 0.52 & 4.67 & 0.70 & 4.60 & 0.68 & 0.916 \\
\hline Developing basketball skills & 4.57 & 1.13 & 4.61 & 0.67 & 4.82 & 0.44 & 4.88 & 0.45 & 4.80 & 0.41 & 0.217 \\
\hline Planning practices & 4.43 & 0.53 & 4.59 & 0.54 & 4.63 & 0.60 & 4.42 & 0.72 & 4.75 & 0.44 & 0.349 \\
\hline Goal setting & 4.71 & 0.49 & 4.69 & 0.55 & 4.78 & 0.42 & 4.58 & 0.65 & 4.80 & 0.41 & 0.558 \\
\hline Giving feedback to players & 4.57 & 0.53 & 4.43 & 0.64 & 4.54 & 0.54 & 4.50 & 0.59 & 4.75 & 0.55 & 0.363 \\
\hline Winning games & 4.14 & 1.07 & 3.61 & 0.92 & 3.92 & 0.86 & 3.71 & 0.95 & 3.55 & 1.10 & 0.301 \\
\hline
\end{tabular}

${ }^{*} \mathrm{p}$ value of ANOVA $<0.05$, and Tukey post hoc test between groups

Table 3 shows that respondents' rating of character attributes. The majority highly rated the importance of the personal attributes. 'Being consistent' $(\mathrm{M}=4.85, \mathrm{SD}=0.39)$ and 'being motivated' $(\mathrm{M}=4.84, \mathrm{SD}=0.41)$ received the highest ratings, while an 'ability to compromise' $(\mathrm{M}=3.95, \mathrm{SD}=0.75)$ had the lowest ratings. A significant difference between the groups was found only in ratings of 'patience', with coaches aged over 55 years finding it more important $(\mathrm{M}=4.90)$ than coaches aged 36-45 year $(\mathrm{M}=4.46)$. The oldest cohort also rated specific attributes higher than other groups. No other differences were observed between the groups. 
Table 3. Average ratings of the importance of character attributes by basketball coaches

\begin{tabular}{lccccccccccc}
\hline \multirow{2}{*}{ Items } & \multicolumn{2}{c}{ Under 23 } & \multicolumn{2}{c}{$\mathbf{2 3 - 3 5}$} & \multicolumn{2}{c}{$\mathbf{3 6 - 4 5}$} & \multicolumn{2}{c}{$\mathbf{4 6 - 5 5}$} & \multicolumn{2}{c}{ over 55 } & \\
\cline { 2 - 9 } & $\mathbf{M}$ & $\mathbf{S D}$ & $\mathbf{M}$ & $\mathbf{S D}$ & $\mathbf{M}$ & $\mathbf{S D}$ & $\mathbf{M}$ & $\mathbf{S D}$ & $\mathbf{M}$ & $\mathbf{S D}$ & $\mathbf{p}$ \\
\hline Patience & 4.86 & 0.38 & 4.51 & 0.61 & $4.46^{*}$ & 0.71 & 4.50 & 0.59 & $4.90^{*}$ & 0.31 & $0.046^{*}$ \\
Tolerance & 4.29 & 0.49 & 4.00 & 0.69 & 4.04 & 0.81 & 3.83 & 0.70 & 4.45 & 0.76 & 0.068 \\
Empathy & 4.14 & 0.90 & 4.06 & 0.68 & 4.18 & 0.75 & 4.13 & 0.95 & 4.45 & 0.60 & 0.420 \\
Humour & 4.00 & 0.58 & 3.90 & 0.73 & 4.28 & 0.64 & 4.04 & 0.69 & 4.15 & 0.88 & 0.117 \\
Optimism & 3.86 & 0.38 & 4.45 & 0.64 & 4.36 & 0.72 & 4.42 & 0.72 & 4.55 & 0.60 & 0.198 \\
Ability to compromise & 4.00 & 0.82 & 3.80 & 0.78 & 3.98 & 0.71 & 3.90 & 0.78 & 4.25 & 0.72 & 0.420 \\
Being ethical & 4.43 & 0.79 & 4.47 & 0.67 & 4.60 & 0.57 & 4.79 & 0.41 & 4.75 & 0.44 & 0.141 \\
Being motivated & 5.00 & 0.00 & 4.76 & 0.47 & 4.86 & 0.40 & 4.83 & 0.38 & 4.90 & 0.31 & 0.500 \\
Being consistent & 4.71 & 0.49 & 4.84 & 0.42 & 4.88 & 0.39 & 4.83 & 0.38 & 4.85 & 0.37 & 0.886 \\
Precision & 4.71 & 0.49 & 4.65 & 0.56 & 4.64 & 0.60 & 4.75 & 0.44 & 4.95 & 0.22 & 0.206 \\
Self-possession & 4.43 & 0.79 & 4.35 & 0.63 & 4.34 & 0.72 & 4.00 & 0.59 & 4.35 & 0.75 & 0.239
\end{tabular}

*p value of ANOVA $<0.05$, and Tukey post hoc test between groups

As regards attitudes and behaviours, the sample was less consistent. Participants unanimously asserted that swearing $(\mathrm{M}=1.50, \mathrm{SD}=0.70)$, physical and verbal abuse $(\mathrm{M}=1.09, \mathrm{SD}=0.35$ and $\mathrm{M}=2.20, \mathrm{SD}=0.94$ respectively), smoking $(\mathrm{M}=1.23, \mathrm{SD}=0.62)$ and drinking alcohol $(\mathrm{M}=1.40, \mathrm{SD}=0.70)$ in the presence of their trainees were all improper behaviour. On the other hand, addressing complaints to referees, was deemed more acceptable $(\mathrm{M}=3.04, \mathrm{SD}=1.00)$; so was the use of individual punishment $(\mathrm{M}=3.62, \mathrm{SD}=1.03)$. Using punishment concurrently with rewards was perceived as more important by the oldest age group $(M=4.25)$ than for the youngest coaches $(M=3.29)$; this difference was statistically significant. Collective punishment, however, was found more acceptable by the 23 to 35 years old (M=4.06) when compared to the coaches aged between 46-55 years $(\mathrm{M}=3.13)$ and coaches aged over 55 years $(\mathrm{M}=2.95)$. Significant differences were also as regards openly addressing conflicts with parents, especially when comparing coaches from the oldest age group ( $M=1.30)$ to those aged between 36 and $45(\mathrm{M}=2.08)$ (Table 4).

Table 4. Average ratings of the importance and acceptability of attitudes and behaviours by basketball coaches

\begin{tabular}{|c|c|c|c|c|c|c|c|c|c|c|c|}
\hline \multirow{2}{*}{ Items } & \multicolumn{2}{|c|}{ Under 23} & \multicolumn{2}{|c|}{ 23-35 } & \multicolumn{2}{|c|}{$36-45$} & \multicolumn{2}{|c|}{$46-55$} & \multicolumn{2}{|c|}{ over 55} & \\
\hline & $\mathbf{M}$ & SD & $\mathbf{M}$ & SD & $\mathbf{M}$ & SD & $\mathbf{M}$ & SD & $\mathbf{M}$ & SD & \\
\hline $\begin{array}{l}\text { It is a pleasure for me to be a } \\
\text { coach }\end{array}$ & 4.86 & 0.38 & 4.73 & 0.53 & 4.64 & 0.60 & 4.67 & 0.56 & 4.85 & 0.37 & 0.571 \\
\hline $\begin{array}{l}\text { Using reward and punishment } \\
\text { equally }\end{array}$ & $3.29 *$ & 1.38 & 4.12 & 0.97 & 4.04 & 1.01 & 3.54 & 1.18 & $4.25^{*}$ & 0.97 & $0.048 *$ \\
\hline Individual punishment & 2.71 & 1.11 & 3.76 & 0.99 & 3.65 & 1.03 & 3.46 & 0.98 & 3.65 & 1.09 & 0.132 \\
\hline Colle & & 1.68 & $4.06^{*}$ & 1.10 & 3.59 & 0.93 & $3.13^{*}$ & 1.04 & $2.95^{*}$ & 1.15 & $0.001 *$ \\
\hline Open & 1.29 & 0.49 & 1.77 & 0.89 & 2.02 & 1.03 & 1.75 & 0.85 & 1.40 & 0.75 & 0.062 \\
\hline Open conflict with parents & 1.29 & 0.49 & 1.73 & 1.90 & $2.08^{*}$ & 1.06 & 1.79 & 0.97 & $1.30^{*}$ & 0.73 & $0.017 *$ \\
\hline $\begin{array}{l}\text { Complaining to referees } \\
\text { during games }\end{array}$ & 2.43 & 1.27 & 3.27 & 0.87 & 3.02 & 1.01 & 3.00 & 0.93 & 2.75 & 1.16 & 0.126 \\
\hline Swearing & 1.43 & 0.79 & 1.63 & 0.75 & 1.53 & 0.77 & 1.50 & 0.59 & 1.10 & 0.31 & 0.077 \\
\hline $\begin{array}{l}\text { Smoking in front of the } \\
\text { players }\end{array}$ & 1.29 & 0.49 & 1.25 & 0.63 & 1.16 & 0.55 & 1.17 & 0.38 & 1.35 & 0.99 & 0.799 \\
\hline $\begin{array}{l}\text { Drinking alcohol in front of } \\
\text { players }\end{array}$ & 1.29 & 0.49 & 1.37 & 0.75 & 1.41 & 0.67 & 1.42 & 0.65 & 1.50 & 0.83 & 0.955 \\
\hline $\begin{array}{l}\text { Denouncing players in front of } \\
\text { the team }\end{array}$ & 1.86 & 1.07 & 2.33 & 0.93 & 2.27 & 0.95 & 2.17 & 1.03 & 1.84 & 0.76 & 0.297 \\
\hline $\begin{array}{l}\text { Physical abuse against a } \\
\text { player }\end{array}$ & 1.14 & 0.38 & 1.06 & 0.24 & 1.14 & 0.46 & 1.03 & 0.41 & 1.00 & 0.00 & 0.550 \\
\hline
\end{tabular}

*p value of ANOVA $<0.05$, and Tukey post hoc test between groups 


\section{Discussion}

This study aimed to explore the effect of age on Hungarian basketball coaches' attitudes and views concerning some important aspects of their job. The age-group boundaries used were based on the assumed differences in experience, expectations and motivations of distinct age cohorts.

Coaches aged less than 23 years may either not possess a coaching certificate or have only earned it in the recent past. Most of the young coaches may still be engaged in playing basketball and they are also less experienced than their older colleagues. Young coaches usually start working with younger teams and gradually progress to the next age-group of players after a couple of years. In all likelihood, young coaches will have a supervisor or a mentor to help them cope with initial difficulties and broaden their knowledge about coaching (Bloom, Durand-Bush, Schinke \& Salmela, 1998), in the early months or years of their careers.

Some of the coaches aged 23-35 years-old are probably active players too; however, they definitely have advanced their professional knowledge in basketball when compared to their younger counterparts. In this age range, some of them are likely to have invested in coaching as a career and undertaken formal learning or an apprenticeship. The majority of coaches aged between 36 and 45 years no longer participate in career sports; furthermore, they now have a better understanding of coaching with sound knowledge and practice on the field especially those who started working earlier. They are usually motivated, ambitious and ready for challenges. Coaches aged over 45 years have most likely worked for a longer period and thereby have an understanding of several age groups in different clubs. They have gained considerable game and life experience and often take on the role of mentoring younger coaches. Despite their extensive experience, the oldest coaches definitely have fewer opportunities for promotion. These coaches grew up and spent most of their playing career in the socialist era where coaches' authority was unquestionable. It is likely that these experiences were imprinted on their attitudes.

A background analysis of our study sample showed that older coaches had more coaching experience, indicating that coaching is a long-term career opportunity in Hungary. They also possessed higher-level certificates in general education level and in formal coaching which contradicts previous findings about Slovene coaches that showed younger coaches were more educated (Kajtna \& Topic, 2017). Despite being more experienced and educated, coaches aged $>55$ years and 45 to 55 years did not usually manage prestigious teams (i.e. $1^{\text {st }}$ or $2^{\text {nd }}$ division senior teams or older age-groups). This was done by 36-45-year-old coaches who occupied the most valued positions. Bias against the older workforce may party explain this finding. It is also possible that older coaches are not perceived in the same light as their younger counterparts by decision-makers.

As regards pedagogical functions, all items were highly rated by all age-groups. There were no consistent patterned differences between the age-groups; the disagreements in each case were seen between two different age-groups only. Although the differences were usually insignificant, coaches aged less than 23 years rated their educational roles slightly lower than older coaches. As novice coaches, they work with the youngest age players where the group composition varies (as younger children are not fully committed team members) and meet the children less often. Therefore, the parents influence on children's involvement dominates (Bruner, Strachan, \& Côté, 2011; Chang \& Mahoney, 2013). Besides this, they may still develop their values, their philosophy is not yet clearly articulated, or they may not be fully aware of the complexity of their jobs. Coaches aged over 55 years however, strongly believed that their educational function surpassed professional aspects, even though some other items related to pedagogical functions were higher rated by other groups. The 36-45-year-old trainers rated the educational function lower, but rated related items like 'character development' and 'teaching values' higher. Since these coaches work with the highest proportion of team members who are older, these coaches may think that other aspects which help enhance performance (e.g. differentiating) should receive more emphasis within their context. Older athletes have already accepted an established team culture and internalized the groups' rules and regulations and therefore their coaches can focus on other facets. Motivating is not only important for learning, performing and enjoying sports participation, but is also recognized by athletes as an attribute of 'good' coaches (Cassidy, Jones \& Potrac, 2009; Petrovska et al., 2020). In our sample, the oldest coaches rated this item highly and this significantly differed from the 46-55 age group.

With respect to professional roles, no significant differences were seen between the age-groups. All coaches attached greater importance to professional knowledge and other elements that contribute to skills development. Because these aspects are vital components of formal coach education programmes, coaches are fully aware of the relevance of planning, goal setting and other teaching priorities. The goal of developing elite players, however, seemed overrated $(\mathrm{M}=3.32)$; nevertheless, this item received the least appreciation within this group of questions. Since one-third of the coached teams belonged to the 'under 12 age-category', the focus should be on participation and building foundations and not elite players (Côté, Bruner, Erickson, Strachan, \& Fraser-Thomas, 2010). Likewise, higher ratings were placed on winning games $(\mathrm{M}=3.74)$, which refers to a highly competitive sports context. Victory is a very powerful motivator 
for coaches, novice coaches tend to overestimate the importance of victory (Strand, Benson, Buck, McGill, \& Smith 2014) and thereby generate stressful environments for players. Considering that the youngest coaches usually work with the youngest players and winning is not usually a priority for children (Meisterjahn \& Dieffenbach, 2008), a victory mentality is unreasonable. However, that in youth sports, parents also tend to overemphasize winning and this may impact young players' attitudes toward performance.

Coaches' personal characteristics are crucial for athletes to benefit from sports participation. Everything coaches do or say conveys meaning and values to athletes and other participants (Cushion, 2010), and largely impacts on the working climate. Patience, tolerance, empathy and an ability to compromise strengthens the bond between participants, enables players to learn at their own pace and reduces stress levels. The relationships coaches build with their athletes determine the efficacy of the whole coaching programme (Jowett, 2017). Better coach-athlete relationships increase the chances of continued participation in youth sports (Gardner, Magee \& Vella, 2017), and aides in performance and overcoming difficult periods for older athletes. Coaches' attributes also create the framework for learning; only motivated, ethical, consistent, accurate and self-possessed coaches can ensure that learning will happen in the right way. Humour is not only appreciated by athletes (Cassidy et al., 2009), but also establishes team identity (Høigaard, Haugen, Johansen, \& Giske 2017). Items related to coaches' personal attributes and professional attitudes were high rated by every age-group; only one significant difference was observed between the oldest coaches and the coaches aged 36 to 45 years regarding 'patience'. This distinction may be explained by the difference in ages of the players coached. Coaches aged over 55 years work with younger teams compared to coaches aged between 36-45 years. For this reason, their goals and ambitions may be different, i.e. learning for younger players and performance for older players. Contrary to previous findings (Posthuma \& Campion, 2009), older coaches' ratings concerning 'being motivated' were rated highly.

Evaluation of coaches' behaviours illustrated similarities and differences by coaches' age. All the three significant differences ('using reward and punishment equally', 'collective punishment' and 'open conflict with parents') were identified between coaches aged over 55 years and one of the under 46-year-old group's ratings. However, the 46-55-years-old age-group also differed from a younger group in one aspect ('collective punishment'). This underpins the findings that most experienced coaches identified their pedagogical function as a top priority.

Punishment is a well-established tradition and a common practice in Hungarian sports and education. The oldest coaches thought that punishment was necessary and rated it higher than other coaches. Conversely, younger coaches also believed that punishment should be applied as often as rewards. Punishment for younger athletes, often takes the form of an exercise (e.g. running, pus-ups, jumping) (Kerr et al., 2016), or a ban from playing during practice or in a competitive game, on the contrary professional players are often fined. Although the acceptability of individual punishment was consistent across age-groups, collective punishment was deemed less acceptable by older coaches. It is probable that during the older coaches' playing careers, collective responsibility was less explicit in basketball when compared to the last decade during which collective punishment became much more apparent. Currently, all players have to submit themselves to the team and understand that the team can only perform well if they adhere to the same rules.

Conflicts between coaches and other people inevitably occur in sports. These situations, when they openly arise, may lead to inappropriate actions that may deter the focus of athletes and the team and draw them away from task at hand. Respondents' responses indicated that they ought to avoid open confrontations with other coaches and parents, however, coaches aged 36-45 years were less likely to do this when compared to the oldest coaches. This finding underpins previous research results about Slovene physical education teachers that had slightly different age-group categorisation (Vrbnjak et al., 2011).

Coaches of different ages fully understood that they ought to not set bad examples to athletes by swearing, smoking or drinking alcohol in the presence of athletes, or by humiliating a player. These findings are consistent with values characteristics of pedagogical roles and responsibilities. Complaining to referees, which is a common occurrence in all levels of competition however, was deemed more acceptable (Gürpınar \& Güven, 2012). Coaches not only tended to exhibit this behaviour but were also unaware of how often they portrayed it (Walters, Schluter, Stamp, Thomson \& Payne, 2016).

Our results showed that coaches, regardless of age, attached a high importance to different aspects of coaching listed in the questionnaire. It was very gratifying that they enjoyed being a coach and highly esteemed the personal development of athletes. Due to the competitive nature of Hungarian sports, professional roles were also relevant for them; however, they were not particularly concerned with developing elite players. Coaches also valued personal characteristics and were well aware of appropriate behaviours.

There were more similarities than differences between the views of different age groups of coaches. Coaches agreed on the importance of most facets of the job and reported being aware of what was expected of them. A possible explanation 
for this may be due to the fact that in sports coaches tend to follow traditions when employing methods and behaviours and reproduce traits of their former coaches (Harvey, Cushion \& Massa-Gonzalez, 2010; Lockwood \& Perlman, 2008; Partington \& Cushion, 2011; Stewart, 2013). Since previous sport-specific experience as an athlete is a prerequisite for all coach training programmes, every respondent had had a prior experience with basketball coaches. Although formal education is mandatory in order to receive a coaching license, informal learning and mentoring seemingly has an immense impact on coaches' views, attitudes and behaviours (Mesquita, Isidro \& Rosado, 2010). Another source of knowledge is experience with a direct connection between experience and knowledge; a minimum of ten years of work experience is required to gain expertise in coaching (Gilbert \& Trudel, 2001; Schempp \& McCullick, 2010; Strand et al., 2014). Our sample was highly experienced, with the majority of coaches aged over 36 years having worked for more than ten years and the oldest cohort for nearly thirty years. Even though experience per se does not build expertise, working in different contexts with different athletes and age-groups definitely broadens a person's understanding of coaching.

These findings indicate that age had no effect on Hungarian basketball coaches' views on narrowly defined professional roles. No definite pattern was observed when comparing pedagogical aspects either by age-group. All the four distinctions (educational role, teaching values, positive environment and motivating) were observed in two or three diverse age-groups. However, examination of coaches' characteristics, behaviours and attitudes showed that coaches aged over 55 years differed from other age-groups in rating patience, use of punishment, collective punishment and conflict management with parents.

Although the ratings of other items did not differ by age group, coaches aged less than 23 years rated pedagogical and professional roles and responsibilities lower than older coaches. The oldest coaches on the other hand, attached more importance to professional roles, personal attributes, attitudes and behaviours.

When interpreting these findings, some limitations ought to be pointed out. Firstly, surveys are wrought with inherent weaknesses of self-reported data. Secondly, despite the sample size including one-third of all basketball coaches working in Hungary, coaches aged less than 23 years were very few. Nevertheless, this present study contributes to the limited literature in this field.

\section{Conclusions}

The aim of this paper was to explore the impact of age on pedagogical and professional values, beliefs and attitudes of Hungarian basketball coaches. Coaches highly rated pedagogical and professional roles and responsibilities, and personal characteristics; they were also familiar with appropriate mannerism. These findings indicate that in Hungary, basketball coaches of different ages share similar viewpoints regarding a range of work-related aspects. Based on this, we can conclude that the age of a coach has no bearing on his/her views on his/her pedagogical and professional roles. Nevertheless, coaches' characteristics, attitudes and behaviours varied with age with significant differences identified between those aged over 55 years and the younger age-groups. Because age correlates with experience, these differences may be as partly explained by differences in experience.

Although individual characteristics and skills should ought not to be ignored when judging a coach's abilities, being cognizant of potential strengths and attitudes of the different age-groups of coaches can help to improve sports' environments for athletes and coaches alike.

\section{References}

Bencsik, A., Juhász, T., \& Horváth-Csikós, G. (2016). Y and Z generations at workplaces. Journal of Competitiveness, 6(3), 90-106. https://doi.org/10.7441/joc.2016.03.06

Bertolino, M., Truxillo, D. M., \& Fraccaroli, F. (2013). Age effects on perceived personality and job performance. Journal of Managerial Psychology, 28(7/8), 867-885. https://doi.org/10.1108/jmp-07-2013-0222

Bloom, G. A., Durand-Bush, N., Schinke, R. J., \& Salmela, J. H. (1998). The importance of mentoring in the development of coaches and athletes. International Journal of Sport Psychology, 29, 267-281.

Bruner, M., Strachan, L., \& Côté, J. (2011). Developmental transitions in sport. In I. Stafford (Ed.), Coaching children in sport (pp. 227-239). Routledge.

Caspi, A., \& Roberts, B. W. (2009). Personality development across the life course: The argument for change and continuity. Psychological Inquiry, 12(2), 49-66. https://doi.org/10.1207/S15327965PLI1202_01

Cassidy, T., Jones, R., \& Potrac, P. (2009). Understanding sports coaching: the social, cultural and pedagogical foundations of coaching practice (2nd ed.). Routledge. https://doi.org/10.4324/9780203892923

Chang, A., \& Mahoney, J. L. (2013). A longitudinal comparison of parent and child influence on sports participation. Journal of Youth Development, 8(3), 68-82. https://doi.org/10.5195/jyd.2013.85 
Côté, J., Bruner, M. W., Erickson, K., Strachan, L., \& Fraser-Thomas, J. (2010). Athlete development and coaching. In J. Lyle \& C. Cushion (Eds.), Sport coaching: Professionalization and practice (pp. 63-83). Elsevier.

Cronin, L. D., \& Allen, J. (2018). Examining the relationships among the coaching climate, life skills development and well-being in sport. International Journal of Sports Science \& Coaching, 13(6), 815-827. https://doi.org/10.1177/1747954118787949

Cushion, C. (2010). Coach behaviour. In J. Lyle \& C. Cushion (Eds.), Sport coaching: Professionalization and practice (pp. 43-61). Elsevier.

Dimec, T., \& Kajtna, T. (2009). Psychological characteristics of younger and older coaches. Kinesiology, 41, 172-180.

Gardner, L., Magee, C., \& Vella, S. (2017). Enjoyment and behavioral intention predict organized youth sport participation and dropout. Journal of Physical Activity and Health, 14, 1-16. https://doi.org/10.1123/jpah.2016-0572

Geeraerts, K., Vanhoof, J., \& Van Den Bossche, P. (2019). Flemish teachers' age-related stereotypes: Investigating generational differences. Journal of Intergenerational Relationships, 1-17. https://doi.org/10.1080/15350770.2019.1701603

Gilbert, W. D., \& Trudel, P. (2001). Learning to coach through experience: Reflection in model youth sport coaches. Journal of Teaching in Physical Education, 21(1), 16-34. https://doi.org/10.1123/jtpe.21.1.16

González-Rivera, M. D., Campos-Izquierdo, A., Villalba, A. I., \& Hall, N. D. (2017). Sources of knowledge used by Spanish coaches: A study according to competition level, gender and professional experience. International Journal of Sports Science \& Coaching, 12(2), 162-174. https://doi.org/10.1177/1747954117694733

Gürpınar, B., \& Güven, Ö. (2012). Unsportsmanlike behaviors in the Turkish basketball and soccer leagues from the view of referees. Pamukkale Journal of Sport Sciences, 3(3), 47-62. https://dergipark.org.tr/en/pub/psbd/issue/20578/219254

Harvey, S., Cushion, C. J., \& Massa-Gonzalez, A. N. (2010). Learning a new method: Teaching games for understanding in the coaches' eyes. Physical Education and Sport Pedagogy, 15(4), 361-382. https://doi.org/10.1080/17408980903535818

Høigaard, R., Haugen, T., Johansen, B. T., \& Giske, R. (2017). Team identity in youth soccer: The role of coaches' feedback patterns and use of humour. International Journal of Sports Science \& Coaching, 12(6), 697-707. https://doi.org/10.1177/1747954117738843

Ilişanu, G., \& Andrei, V. (2018). Age stereotypes and ageism at the workplace - \#ageisjustanumber. Journal of Comparative Research in Anthropology and Sociology, 9(2), 23-33. https://doaj.org/article/73b4ce9266694d64be7193103bd6f20e

Jowett, S. (2017). Coaching effectiveness: The coach-athlete relationship at its heart. Current Opinion in Psychology, 16, 154-158. https://doi.org/10.1016/j.copsyc.2017.05.006

Kajtna, T., \& Topic, M. D. (2017). Attitudes of coaches considered by their gender, the sports and the athletes they coach. Ido Movement for Culture, 17(3), 48-55. doi:10.14589/ido.17.3.6

Kerr, G., Stirling, A., MacPherson, E., Banwell, J., Bandealy, A., \& Preston, C. (2016). Exploring the use of exercise as punishment in sport. International Journal of Coaching Science, 10(2), 34-52.

Kühl, S. J., Schneider, A., Kestler, H. A., Toberer, M., Kühl, M., \& Fischer, M. R. (2019). Investigating the self-study phase of an inverted biochemistry classroom - collaborative dyadic learning makes the difference. BMC Medical Education, 19, Article 64. https://doi.org/10.1186/s12909-019-1497-y

Lockwood, P., \& Perlman, D. J. (2008). Enhancing the youth sport experience: A re-examination of methods, coaching style, and motivational climate. The Journal of Youth Sports, 4(1), 30-34.

Meisterjahn, R., \& Dieffenbach, K. (2008). Winning vs. participation in youth sports: Kids' values and their perception of their parents' attitudes. Journal of Youth Sports, 4(1), 4-7.

Merkel D. L. (2013). Youth sport: Positive and negative impact on young athletes. Open Access Journal of Sports Medicine, 4, 151-60. https://doi.org/10.2147/OAJSM.S33556

Mesquita, I., Isidro, S., \& Rosado, A. (2010). Portuguese coaches' perceptions of and preferences for knowledge sources related to their professional background. Journal of Sports Science \& Medicine 9(3), 480-489.

Miller, S., \& Siegel, J. (2017). Youth sports and physical activity: The relationship between perceptions of childhood sport experience and adult exercise behavior. Psychology of Sport and Exercise, 33, 85-92. 
https://doi.org/10.1016/j.psychsport.2017.08.009

Ng, T. W., \& Feldman, D. C. (2012). Evaluating six common stereotypes about older workers with meta-analytical data. Personnel Psychology, 65(4), 821-858. https://doi.org/10.1111/peps.12003

Norman, G. (2010). Likert scales, level of measurement and the "laws" of statistics. Advances in Health Sciences Education, 15(5), 625-632. https://doi.org/10.1007/s10459-010-9222-y

North, M. S., \& Fiske, S. T. (2012). An inconvenienced youth? Ageism and its potential intergenerational roots. Psychological Bulletin, 138(5), 982-997. https://doi.org/10.1037/a0027843

Ocak, G., Özçalişan, H., \& Kuru, N. (2010). The student attitudes in terms of the usage of English activities and materials and their contributions to English learning process. Procedia Social and Behavioral Sciences, 2(2), 560-564. https://doi.org/10.1016/j.sbspro.2010.03.063

Partington, M., \& Cushion, C. (2011). An investigation of the practice activities and coaching behaviors of professional top-level youth soccer coaches. Scandinavian Journal of Medicine \& Science in Sports, 23(3), 374-382. https://doi.org/10.1111/j.1600-0838.2011.01383.x

Petrovska, T., Sova, V., Khmelnitska, I., Borysova, O., Imas, Y., Malinovskyi, A., \& Tereschenko, L. (2020). Research of football coach's professionally important qualities in football player's perception. Journal of Physical Education and Sport, Suppl. 1, Art.63, 435-440. https://doi.org/10.7752/jpes.2020.s1063

Posthuma, R. A., \& Campion, M. A. (2009). Age stereotypes in the workplace: Common stereotypes, moderators, and future research directions. Journal of Management, 35(1), 158-188. https://doi.org/10.1177/0149206308318617

Prichard, A., \& Deutsch, J. (2015). The effects of motivational climate on youth sport participants. The Physical Educator, 72(5), 200-214. https://doi.org/10.18666/TPE-2015-V72-I5-6999

Rottensteiner, C., Laakso, L., Pihlaja, T., \& Konttinen, N. (2013). Personal reasons for withdrawal from team sports and the influence of significant others among youth athletes. International Journal of Sports Science \& Coaching, 8(1), 19-32. https://doi.org/10.1260/1747-9541.8.1.19

Schempp, P. G., \& McCullick, B. (2010). Coaches' expertise. In J. Lyle \& C. Cushion (Eds.), Sport coaching: Professionalization and practice (pp. 221-231). Elsevier.

Schwaba, T., \& Bleidorn, W. (2017). Individual differences in personality change across the adult life span. Journal of Personality, 86(3), 450-464. https://doi.org/10.1111/jopy.12327

Smola, K. W., \& Sutton, C. D. (2002). Generational differences: Revisiting generational work values for the New Millenium. Journal of Organizational Behavior, 23, 363-382. https://doi.org/10.1002/job.147

Stewart, C. (2013). The Negative Behaviors of Coaches: "Don't Be This Guy!". Physical Educator, 70(1), 1-14.

Strachan, L., Côté, J., \& Deakin, J. (2011). A new view: Exploring positive youth development in elite sport contexts. Qualitative Research in Sport, Exercise and Health, 3(1), 9-32. https://doi.org/10.1080/19398441.2010.541483

Strand, B., Benson, D., Buck, R., McGill, W., \& Smith, D. (2014). The characteristics of coaching expertise. Virginia Journal, 35(2), 4-7.

Vrbnjak, S., Videmšek, M., \& Štihec, J. (2011). An analysis of conflict management strategies in physical education classes depending on a teacher's age. Kinesiologia Slovenica, 17(2), 5-13.

Walters, S., Schluter, P., Stamp, D., Thomson, R., \& Payne, D. (2016). Coaches and referees' perspectives of sideline behaviour in children's team sports: A cross-sectional study. International Journal of Sport Management Recreation \& Tourism, 23, 51-74. https://doi.org/10.5199/ijsmart-1791-874X-23c

Watson, J. C. II, Connole, I., \& Kadushin, P. (2011). Developing young athletes: A sport psychology based approach to coaching youth sports. Journal of Sport Psychology in Action, 2, 113-122. https://doi.org/10.1080/21520704.2011.586452

\section{Copyrights}

Copyright for this article is retained by the author(s), with first publication rights granted to the journal.

This is an open-access article distributed under the terms and conditions of the Creative Commons Attribution license which permits unrestricted use, distribution, and reproduction in any medium, provided the original work is properly cited. 